\title{
FUNGSI DAN KEGUNAAN MOBIL BARANG MENURUT UU NO. 22 TAHUN 2009 TENTANG LALULINTAS DAN ANGKUTAN JALAN
}

\author{
Oleh \\ Joejoen Tjahjani \\ Dosen Fakultas Hukum Universitas Islam Lamongan
}

\begin{abstract}
ABSTRAK
Dalam kehidupan sehari-hari kebutuhan akan sarana tranportasi kian hari dirasakan semakin meningkat sesuai dengan laju perkembangan jaman, sehingga kebutuhan dalam hal ini sudah tidak dapat ditunda-tunda lagi, bahkan sekarang sudah berubah menjadi suatu kebutuhan primer. Manusia yang hidup dalam lingkup masyarakat mempunyai hak untuk menghormati hak asasi orang lain, seperti contohnya dalam hal berlalu lintas. Dalam penelitian ini penulis menggunakan metode yuridis normatif, dan pendekatan yang dilakukan dalam penelitian ini menggunakan pendekatan perundang undangan, untuk bahan hukum dalam penulisan skripsi ini penulis menggunakan bahan-bahan hukum yang meliputi bahan hukum primer dan bahan hukum sekunder, dalam prosedur pengumpulan bahan hukum baik bahan hukum primer maupun dengan bahan hukum sekunder dikumpulkan berdasarkan topik permasalahan yang telah dirumuskan dan diklarifikasi menurut sumber dan hirarkinya untuk dikaji secara komprehensif, serta pengolahan dan analisis bahan hukum, adapun bahan hukum yang diperoleh dalam penelitian adalah studi kepustakaan, aturan perundangundangan, yang penulis uraikan dan dihubungkan sedemikian rupa, sehingga disajikan dalam penulisan yang lebih sistematis. pengaturan mengenai fungsi dan kegunaan mobil barang menurut undang-undang no. 22 tahun 2009 tentang lalu lintas dan angkutan jalan mempunyai peran strategis dalam mendukung pembangunan dan integrasi nasional sebagai bagian dari upaya memajukan kesejahteraan umum sebagaimana diamanatkan oleh Undang-Undang Dasar Negara Republik Indonesia Tahun 1945. Pertanggungjawaban pidana terhadap pelanggaran lalu lintas yang menyalahgunakan mobil barang untuk mengangkut orang/manusia yang diatur dalam undang-undang no. 22 tahun 2009 tentang lalu lintas dan angkutan jalan. Kepolisian seharusnya tetap profesional dalam menjalankan peran, fungsi, dan tugasnya sebagai aparat penegak hukum dengan memberikan tindakan yang tegas lebih mengoptimalkan lagi sosialisasi Undang-Undang Lalu Lintas Dan Angkutan Jalan.
\end{abstract}

Kata kunci: Fungsi, Kegunaan, Mobil Barang, Lalu Lintas, Angkutan Jalan.

\section{PENDAHULUAN \\ Latar belakang}

Kepadatan penduduk yang terus bertambah, kebutuhan orang yang semakin banyak, serta kemajuan teknologi yang semakin canggih membawa dampak semakin ramainya transportasi di jalanan. Secara sederhana lalu lintas dapat dipahami sebagai pergerakan orang dan kendaraan di jalan. Selain itu, untuk menunjang sistem kelancaran transportasi juga diperlukan sistem lalu lintas yang aman untuk berkendara.

Pelaksanaan undang-undang no. 22 tahun 2009 tentang lalu lintas dan angkutan jalan termasuk hukum pidana, Keberadaan hukum pidana dalam kehidupan bernegara memilikiperanan 
yang penting, sebab tugas hukum pidana adalah menjadi obat terakhir dengan memberikan sanksi kepada si pelanggar hukum berupa pembatasan-pembatasan tertentu guna menjamin terciptanya kedamaian dan ketentraman di dalam masyarakat.

Penghilangan nyawa manusia memang dapat dilakukan oleh siapa saja, tidak terkecuali anak yang masih dibawah umur maupun orang dewasa sekalipun. Namun kalau dikalkulasi, penyebab kematian oleh karena penggunaan lalu lintas jalan sebagai akibat adanya kecelakaan kendaraan bermotor saat ini memberikan andil cukup besar sebagai penyebab utama yang mengakibatkan hilangnya nyawa bahkan harta benda milik manusia.

\section{Tujuan penelitian}

Terpenuhinya akan sarana transportasi yang memadai di satu sisi harus diimbangi dengan melengkapi berbagai sarana atau fasilitas penunjang sebagai pendukung. Di sisi lain, perangkat peraturan aparat serta fasilitas jalan harus memadai. Perangkat peraturan di bidang lalu lintas yang berlaku secara nasional saat ini berfungsi sebagai sarana preventive untuk mengatasi bahkan meniadakan timbulnya kecelakaan lalu lintas jalan raya yang dilakukan oleh anak dibawah umur.

\section{METODE PENELITIAN Tipe Penelitian}

Tipe penelitian hukum yang dilakukan adalah yuridis normatif (hukum normatif). Metode penelitian hukum normatif adalah penelitian hukum yang dilakukan dengan cara meneliti bahan pustaka atau data sekunder, dan bahan hukum tersier. Bahan-bahan hukum tersebut disusun secara sistematis, dikaji kemudian ditarik suatu kesimpulan dalam hubungannya yang diteliti. ${ }^{32}$

\footnotetext{
${ }^{32}$ Soerjono Soekanto, Pengantar Penelitian Hukum, UI Press, Jakarta, 2008, hlm 54
}

Oleh karena itu penelitian hukum ini difokuskan untuk mengkaji penelitian hukum tentang kaidah-kaidah atau normanorma dalam hukum positif.

\section{Pendekatan masalah}

Pendekatan yang dilakukan dalam penelitian ini menggunakan pendekatan perundang undangan (statueekata approach), pendekatan perundang undangan adalah pendekatan yang dilakukan oleh peneliti melalui aturan perundang undangan yang berkaitan dengan materi yang dibahas. Selain itu juga digunakan pendekatan kasus (case approach). Pendekatan kasus digunakan untuk melihat kasus-kasus tindak pidana kealpaan.

\section{Bahan hukum}

Dalam penulisan skripsi ini penulis menggunakan bahan-bahan hukum yang meliputi :

a) Bahan hukum primer :

Bahan hukum primer adalah merupakan bahan hukum yang bersifat autoriatif, artinya mempunyai otoritas. Bahan-bahan hukum terdiri dari perundang-undangan, catatan-catatan resmi, atau risalah dalam pembuatan perundang-undangan dan putusan-putusan hakim. ${ }^{33}$

Adapun bahan hukum primer tersebut meliputi :

1) Undang-Undang Dasar 1945,

2) Kitab Undang-Undang Hukum Pidana (KUHP),

3) undang undang nomor 22 tahun 2009 tentang lalu lintas dan angkutan jalan.

4) Peraturan pemerintah nomor 55 tahun 2012tentang kendaraan,

5) Peraturan pemerintah nomor 80 tahun 2012 tentang tata cara pemeriksaan kendaraan bermotor di

\footnotetext{
${ }^{33}$ Peter Mahmud Marzuki, Penelitian Hukum, Prenadamedia Group, Jakarta, 2016, hlm. 181.
} 
jalan dan penindakan pelanggaran lalu lintas dan angkutan jalan.

6) Peraturan pemerintah nomor 74 tahun 2014 tentang angkutan jalan.

b) Bahan Sekunder

Bahan hukum sekunder adalah bahan yang diperoleh dari buku teks, karena buku teks berisi mengenai prinsip-prinsip dasar ilmu hukum dan pandangan-pandangan klasik para sarjana yang mempunyai kuwalitas tinggi. ${ }^{34}$

\section{Prosedur pengumpulan bahan hukum}

Baik bahan hukum primer maupun dengan bahan hukum sekunder dikumpulkan berdasarkan topik permasalahan yang telah dirumuskan dan diklarifikasi menurut sumber dan hirarkinya untuk dikaji secara komprehensif.

\section{Pengolahan dan analisis bahan hukum}

Adapun bahan hukum yang diperoleh dalam penelitian adalah studi kepustakaan, aturan perundang-undangan, yang penulis uraikan dan dihubungkan sedemikian rupa, sehingga disajikan dalam penulisan yang lebih sistematis guna menjawab perumusan masalah yang dirumuskan. Cara pengolahan bahan hukum dilakukan secara deduktif yakni menarik kesimpulan dari suatu pemasalahan yang bersifat umum terhadap permasalahan konkrit yang dihadapi yakni tindak pidana kealpaan.

\section{HASIL PENELITIAN DAN \\ PEMBAHASAN \\ HASIL PENELITIAN}

Pengaturan mengenai fungsi dan kegunaan mobil barang menurut undang-undang no. 22 tahun 2009 tentang lalu lintas dan angkutan jalan.

${ }^{34}$ Ibid, hlm. 182. pengaturan mengenai fungsi dan kegunaan mobil barang menurut undangundang no. 22 tahun 2009 tentang lalu lintas dan angkutan jalan mempunyai peran strategis dalam mendukung pembangunan dan integrasi nasional sebagai bagian dari upaya memajukan kesejahteraan umum sebagaimana diamanatkan oleh Undang-Undang Dasar Negara Republik Indonesia Tahun 1945.

Adapun definisi mobil penumpang dan mobil barang yang diatur dalam pasal 1 angka 5 peraturan pemerintah no. 55 tahun 2012 tentang kendaraan, dan juga dijelaskan pasal 1 angka 7 peraturan pemerintah no. 55 tahun 2012 tentang kendaraan.

Pengangkutan berasal dari kata dasar "angkut" yang berarti angkat dan bawa, muat dan bawa atau kirimkan. Mengangkut artinya mengangkat dan membawa, memuat dan membawa atau mengirimkan. Pengangkutan artinya pengangkatan dan pembawaan barang atau orang, pemuatan dan pengiriman barang atau orang, barang atau orang yang diangkut. Jadi, dalam pengertian pengangkutan itu tersimpul suatu proses kegiatan atau gerakan dari satu tempat ke tempat lain. ${ }^{35}$

mobil barang adalah Kendaraan Bermotor yang digunakan untuk angkutan barang. Mobil barang lebih populer dikenal sebagai truk yang berasal dari bahasa Inggris Truck atau prahoto ayang berasal dari bahasa Belanda vrachtauto. Dalam bentuk kecil disebut pick-up.

Adapun jenis-jenis mobil barang:

1. Truk barang umum, merupakan truk yang digunakan untuk mengangkut segala jenis barang, baik yang dikemas ataupun tanpa kemasan dalam bentuk curah, namun penggunaan yang

\footnotetext{
${ }^{35}$ Abdul Kadir Muhammad, Hukum Pengangkutan Darat, Laut, dan Udara, PT.Citra Aditya Bakti,1991, Bandung, hlm 19.
} 
sifatnya spesifik sering diangkat dengan truk yang diperuntukkan untuk satu jenis barang saja.

2. Truk tangki adalah truk yang dirancang untuk mengangkut muatan berbentuk cair atau gas. Untuk meningkatkan kestabilan dalam transportasi cairan dalam tangki, tangki dibagi dalam beberapa kompartemen yang dipisahkan dengan sekat-sekat.

3. Mobil box adalah kendaraan angkutan barang antaran yang biasanya digunakan untuk mengangkut barang antaran (delivery van) yang dimasukkan dalam suatu box yang terbuat dari baja ataupun dari aluminium. Dengan box ini barang akan terlindungi dari hujan dan angin dan disamping itu juga melindungi barang dari tangan-tangan jahil. Ada pula truk box yang dilengkapi dengan pendingin yang digunakan untuk mengangkut barang yang mudah busuk atau rusak karena suhu seperti untuk angkutan es, daging, ikan, sayuran dan buah-buahan.

Mobil peti kemas disebut juga truk kontainer adalah kendaraan pengangkut peti kemas terdiri dari kendaraan penarik (tractor head) dan kereta tempelan dimana peti kemas ditempatkan. Trend angkutan barang dengan peti kemas meningkat dengan cepat karena intermodalitynya yang tinggi sehingga mempermudah bongkar-muat/handling dari barang yang mengakibatkan biaya angkutan secara keseluruhan menurun dengan drastis. Disamping itu keamanan dari barang juga lebih tinggi. ${ }^{36}$

Pertanggungjawaban pidana terhadap pelanggaran lalu lintas yang menyalahgunakan mobil barang untuk mengangkut orang/manusia yang diatur dalam undang-undang no. 22 tahun

\footnotetext{
${ }^{36}$ https://id.wikibooks.org/wiki/Moda_Transportasi/Moda _Transportasi_Jalan
}

\section{9 tentang lalu lintas dan angkutan jalan.}

Pertanggungjawaban pidana terhadap pelanggaran lalu lintas yang menyalahgunakan mobil barang untuk mengangkut orang/manusia yang diatur dalam undang-undang no. 22 tahun 2009 tentang lalu lintas dan angkutan jalan, di dalam pelanggaran lalu lintas, pertanggungjawaban pidana terhadap pelanggar lalu lintas yang menyalah gunakan mobil barang digunakan untuk mengangkut orang yakni di atur dalam undang undang no. 22 tahun 2009 tentang lalu lintas dan angkutan jalan bagian ketiga kewajiban dan tanggung jawab.

Pelanggaran adalah tindak pidana yang termasuk lebih ringan dari kejahatan. pelanggaran lalu lintas adalah pelanggaran-pelanggaran yang khusus dilakukan oleh pengemudi kendaraan bermotor dijalan raya.

Dengan demikian suatu tindakan dinyatakan telah melanggar apabila hakikat dari perbuatan itu menimbulkan adanya sifat melawan hukum dan telah ada aturan dan atau telah ada undang-undang yang mengaturnya. Walaupun perbuatan itu telah menimbulkan suatu sifat yang melanggar hukum, namun belum dapat dinyatakan sebagai suatu bentuk pelanggaran sebelum diatur dalam peraturan perundang-undangan.

Untuk penjelasannya pengemudi, pemilik Kendaraan Bermotor, dan atau Perusahaan Angkutan Umum bertanggung jawab atas kerugian yang diderita oleh Penumpang dan atau pemilik barang dan atau pihak ketiga karena kelalaian pengemudi seperti ugal - uagalan dijalan raya dan wajib memberikan bantuan kepada ahli waris korban berupa biaya pengobatan dan atau biaya pemakaman dengan tidak menggugurkan tuntutan perkara pidana. Para pengguna kendaraan seperti mobil, motor dan angkutan umum harus selalu berhati - hati dalam menyetir 
agar tidak membahayakan diri sendiri dan orang lain.

Di pengadilan, pelaku yang lalai dijerat dengan Pasal 359-360 KUHP. Bahkan setelah UU Lalu Lintas dan Angkutan Jalan (UU No. 22 Tahun 2009) berlaku pun Pasal 359-360 KUHP masih sering dipakai polisi dan jaksa.

Pasal 359

"Barang siapa karena kealpaannya menyebabkan matinya orang lain, di ancam dengan pidana penjara paling lama lima tahun atau kurungan paling lama satu tahun"

Pasal 360

(1) "Barang siapa karena kealpaannya menyebakan orang lain mendapat luka-luka berat, diancam dengan pidana penjara paling lama lima tahun atau kurungan paling lama satu tahun.

(2) Barang siapa karena kealpaannya menyebabkan orang lain luka-luka sedemikian rupa sehinga menimbulkan penyakit atau alangan menjalankan pekerjaan, jabatan atau pencaharian selama waktu tertentu, diancam dengan pidana penjara paling lama sembilan bulan atau denda paling tinggi tiga ratus rupiah.

\section{PEMBAHASAN}

Pengaturan dalam undang-undang no. 22 tahun 2009 tentang lalu lintas dan angkutan jalan Lalu Lintas dan Angkutan Jalan mempunyai peran strategis dalam mendukung pembangunan dan integrasi nasional sebagai bagian dari upaya memajukan kesejahteraan umum sebagaimana diamanatkan oleh UndangUndang Dasar Negara Republik Indonesia Tahun 1945. Selain itu, Lalu Lintas dan Angkutan Jalan juga sebagai bagian dari sistem transportasi nasional harus dikembangkan potensi dan perannya untuk mewujudkan keamanan, keselamatan, ketertiban, dan kelancaran berlalu lintas dan Angkutan Jalan dalam rangka mendukung pembangunan ekonomi dan pengembangan wilayah. Maka dari itu, ditetapkanlah Undang-undang Nomor 22 Tahun 2009 tentang Lalu Lintas dan Angkutan Jalan.

Di dalam pelanggaran lalu lintas, pertanggungjawaban pidana terhadap pelanggar lalu lintas yang menyalah gunakan mobil barang digunakan untuk mengangkut orang yakni di atur dalam undang undang no. 22 tahun 2009 tentang lalu lintas dan angkutan jalan bagian ketiga kewajiban dan tanggung jawab. Di pengadilan, pelaku yang lalai dijerat dengan Pasal 359-360 KUHP. Bahkan setelah UU Lalu Lintas dan Angkutan Jalan (UU No. 22 Tahun 2009) berlaku pun Pasal 359-360 KUHP masih sering dipakai polisi dan jaksa.

\section{KESIMPULAN DAN SARAN}

\section{KESIMPULAN}

Dari uraian mengenai fungsi dan kegunaan mobil barang menurut undangundang no. 22 tahun 2009 tentang lalu lintas dan angkutan jalan, maka dapat disimpulkan bahwa;

1. pengaturan mengenai fungsi dan kegunaan mobil barang menurut undang-undang no. 22 tahun 2009 tentang lalu lintas dan angkutan jalan mempunyai peran strategis dalam mendukung pembangunan dan integrasi nasional sebagai bagian dari upaya memajukan kesejahteraan umum sebagaimana diamanatkan oleh Undang-Undang Dasar Negara Republik Indonesia Tahun 1945. Adapun definisi mobil penumpang dan mobil barang yang diatur dalam pasal 1 angka 5 peraturan pemerintah no. 55 tahun 2012 tentang kendaraan, dan juga 
dijelaskan pasal 1 angka 7 peraturan pemerintah no. 55 tahun 2012 tentang kendaraan.

2. Pertanggungjawaban pidana terhadap pelanggaran lalu lintas yang menyalahgunakan mobil barang untuk mengangkut orang/manusia yang diatur dalam undang-undang no. 22 tahun 2009 tentang lalu lintas dan angkutan jalan, di dalam pelanggaran lalu lintas, pertanggungjawaban pidana terhadap pelanggar lalu lintas yang menyalah gunakan mobil barang digunakan untuk mengangkut orang yakni di atur dalam undang undang no. 22 tahun 2009 tentang lalu lintas dan angkutan jalan bagian ketiga kewajiban dan tanggung jawab.

\section{SARAN}

Berdasarkan setelah menganalisa datadata yang ada, maka saran penulis mengenai fungsi dan kegunaan mobil barang menurut undang-undang no. 22 tahun 2009 tentang lalu lintas dan angkutan jalan, yakni;

1. Aparat kepolisian seharusnya tetap profesional dalam menjalankan peran, fungsi, dan tugasnya sebagai aparat penegak hukum dengan memberikan tindakan yang tegas lebih mengoptimalkan lagi sosialisasi Undang-Undang Lalu Lintas Dan Angkutan Jalan, karena bisa dilihat masyarakat masih banyak yang tidak pernah mengikuti sosialisasi. Karena bagaimanapun juga, jika sosialisasi terhadap Undang-Undang sudah optimal, maka masyarakat akan mengetahui kehadiran dan tujuan yang hendak dicapai dari Undang-Undang tersebut dan besar kemungkinan juga masyarakat akan mentaati peraturan tersebut.

2. Pemerintah harus lebih memperhatikan sarana atau fasilitas seperti penambahan pos polisi di jalan-jalan umum, karena apabila suatu aturan sudah difungsikan sementara fasilitasnya belum tersedia atau tidak memadai maka akan mengakibatkan aturan tersebut tidak akan berfungsi.

\section{DAFTAR PUSTAKA}

\section{LITERATUR}

a. Abdul Kadir Muhammad, Hukum Pengangkutan Darat, Laut, dan Udara, Penerbit PT.Citra Aditya Bakti, Bandung.1991.

b. Farouk muhammad, praktik penegakan hukum bidang lalu lintas, balai pustaka, jakarta, 1999.

c. Ilham Bisri, Sistem Hukum Indonesia (Prinsip-prinsip dan Implementasi Hukum di Indonesia), PT RajaGrafindo Persada, Jakarta 2014.

d. Moeljatno, Asas-asas Hukum Pidana, PT Rineka Cipta, Jakarta, 2008.

e. Peter Mahmud Marzuki, Penelitian Hukum, Prenadamedia Group, Jakarta, 2016.

f. R. Abdoel Djamali, pengantar hukum indonesia, PT. Rajagrafindo Persada, Jakara, 2011.

g. Ridwan Khairandy., pokok-pokok hukum dagang di indonesia, Yogyakarta, FH UII Press, 2013.

h. Soegijanta Tjakranegara, Hukum Pengangkutan Barang dan Penumpang, Rineka Cipta, Jakarta, 2005.

i. Soerjono Soekanto. Polisi Lalu Lintas Analisa Menurut Sosiologi Hukum. Maju Mundur. Bandung. 1990.

j. Soerjono Soekanto, Pengantar Penelitian Hukum, UI Press, Jakarta, 2008.

k. Teguh Prasetyo, Hukum Pidana, PT Rajagrafindo persada, Jakarta,2013.

\section{PERUNDANG-UNDANGAN}

a. Undang-Undang Dasar 1945 
b. Kitab Undang-Undang Hukum Pidana (KUHP)

c. undang undang nomor 22 tahun 2009 tentang lalu lintas dan angkutan jalan.

d. Peraturan pemerintah nomor 55 tahun 2012tentang kendaraan

e. Peraturan pemerintah nomor 80 tahun 2012 tentang tata cara pemeriksaan kendaraan bermotor di jalan dan penindakan pelanggaran lalu lintas dan angkutan jalan f. Peraturan pemerintah nomor 74 tahun 2014 tentang angkutan jalan

\section{INTERNET}

a. https://www.polri.go.id/tentangtilang.php

b. https://id.wikibooks.org/wiki/Moda_Tr ansportasi/Moda Transportasi Jalan

c. http://argawahyu.blogspot.co.id/2011/ 06/hukum-pengangkutan.html 